\title{
BAIK BURUK DALAM PRESPEKTIF ILMU AKHLAK
}

\author{
Mustopa \\ IAIN Syekh Nurjati Cirebon
}

\begin{abstract}
Abstrak: Setiap manusia ingin memperolah kehidupan yang baik bahkan yang terbaik. Setiap manusia memiliki sikap dan perangai sendiri-sendiri. Apabila seseorang memiliki sikap atau perangai yang baik, maka orang yang demikian dianggap memiliki akhlak yang baik, Sebaliknya jika ada orang yang memiliki sikap dan perangai yang jelek maka orang tersebut dianggap memiliki akhlak yang jelek. Baik buruk tentu memiliki ukuran yang tidak sama, halini terbukti dengan adanya sesuatu yang baik menurut seseorang/kelompok tapidianggaptidak baikoleh kelompoklainnya.Untuk kepentingan memahami baik dan buruk tentu diperlukan adanya standar yang dapat dijadikan ukuran untuk menentukan baik buruk.
\end{abstract}

Kata Kunci : Akhlak, Baik dan Buruk.

\section{A. Pendahuluan}

Pengertian baik dan buruk ada yang subyektif dan relatif, baik bagi seseorang belum tentu baik bagi orang lain. Sesuatu itu baik bagi seseorang apabila hal itu sesuai dan berguna untuk tujuannya. Hal yang sama adalah mungkin buruk bagi orang lain, karena hal terseut tidak akan berguna bagi tujuannya. Masing-masing orang mempunyai tujuannya yang berbeda-beda, bahkan ada yang bertentangan, sehingga yang berharga untuk seseorang atau untuk golongan berbeda dengan yang berharga untuk orang atau golongan lainnya.

Akan tetapi secara byektif, walaupun tujuan orang atau golongan di dunia ini berbeda-beda, sesungguhnya pada akhirnya semuanya mempunyai tujuan yang sama, sebagai tujuan akhir tiaptiap sesuatu, bukan saja manusia bahkan binatang pun mempunyai 
tujuan. Dan tujuan akhir dari semua itu sama, yaitu bahwa semuanya ingin baik. Dengan kata lain semuanya ingin bahagia. Tak ada seorang pun dan sesuatu pun yang tidak ingin bahagia.

Tujuan dari asing-masing sesuatu, walaupun berbeda-beda, semuanya akan bermuara kepada satu tujuan yang dinamakan baik, semuanya mengharapkan mendapatkan yang baik dan bahagia, tujuan yang akhir yang sama ini dalam ilmu Ethik "Kebaikan Tertinggi", yang dengan istilah Latinnya disebut "Summum Bonum" atau bahasa Arabnya Al-Khair al-Kully. Kebaikan tertinggi ini bisa juga disebut kabahagiaan yang universal atau Universal Happiness.

\section{B. Pembahasan}

\section{Pengertian Akhlak}

Kata akhlak sesungguhnya tidak asing lagi bagi telinga kita, karena kata ini sering kita dengar dalam kehidupan sehari-hari. Kata akhlak seringkali dikonotasikan dengan istilah baik, contohnya orang itu berakhlak. Maksudnya orang itu baik. ${ }^{1}$

Manusia perlu memiliki akhlak yang baik agar bisa diterima di masyarakat dan hidup di dalamnya. Jika manusia memeiliki akhlak yang jelek maka hidupnya akan dikucilkan oleh masyarakat, dan akan dikucilkan dari kehidup

Terkait dengan istilah akhlak, untuk memahaminya, paling tidak ada dua pendekatan yang dapat digunakan untuk mendefinisikan arti akhlak, yaitu dengan pendekatan linguistik (kebahasaan), dan dengan pendekatan terminologik (peristilahan). ${ }^{2}$

Kata akhlak secara kebahasaan, berasal dari bahasa Arab, yaitu isim mashdar (bentuk infinitif) dari kata akhlaqa, yukhliqu, ikhlaqan, sesuai dengan timbangan (wazan) tsulasi majid: af'ala,

${ }^{1}$ Beni Akhmad Saebani dan Abdul Hamid, ${ }^{1}$ dalam bukunya yang berjudul Imu Akhlak menjelaskan bahwa akhlak terpuji memiliki indikator. Adapun indikator utama dari perbuatan yang baik atau akhlak yang baik adalah sebagai berikut. a. Perbuatan yang diperintahkan oleh ajaran Allah swt dan Rasulullah SAW yang termuat di dalam Al-Quran dan As-Sunnah. b. Perbuatan yang mendatangkan kemaslahatan dunia dan akhirat. c. Perbuatan yang meningkatkan martabat kehidupan manusia di mata Allah dan sesama manusia. d. Perbuatan yang menjadi bagian dari tujuan syariat Islam, yaitu me-melihara agama Allah, akal, jiwa, keturunan, dan harta kekayaan.

2 Abuddin Nata. Akhlak Tasawuf dan Karakter Mulia. Jakarta; PT. Raja Grapindo Persada. 2014., hlm. 1. 
yuf'ilu if'alan yang berarti al-sajiyah (perangai), ath-thabi'ah (kelakuan, tabi'at, watak dasar), al-'adat (kebiasaan, kelaziman), al-maru'ah (peradaban yang baik), dan al-din (agama). ${ }^{3}$

Rachmat Djatnika menjelaskan kata akhlak berasal dari bahasa Arab Akhlâq bentuk jama dari mufradnya adalah khuluq, yang berarti "budi pekerti". Sinonimnya : etika dan moral. Etika berasal dari bahasa Latin, etos yang berarti "kebiasaan". Moral berasal dari bahasa Latin juga, mores, juga berarti "kebiasaannya". ${ }^{4}$ Kata akhlak secara etimologi (arti bahasa) menurut pendapat Zakiah Darajat berasal dari kata khalaqa, yang kata asalnya khuluqun, yang berarti : perangai, tabiat, adat atau khalqun yang berarti kejadiaan, buatan, ciptaan. Jadi secara etimologi akhlak itu berarti perangai, adat, tabiat, atau sistem perilaku yang dibuat. ${ }^{5}$

Selain pengertian akhlak secara bahasa, akhlak pun bisa dipahami maknanya dari segi terminologi (istilah. Adapun pengertian akhlak secara terminologi dapat dipahami dari apa yang dijelaskan oleh beberapa ahli berikut ini:

1. Ahmad Amin memberikan penjelasan bahwa akhlak adalah menangnya keinginan dari beberapa keinginan manusia dengan langsung dan berturut. ${ }^{6}$

2. Ibn Miskawaih. ${ }^{7}$ Menjelaskan bahwa "Akhlak adalah : Sifat yang tertanam dalam jiwa yang memotivasinya untuk melakukan perbuatan tanpa memerlukan pemikiran dan pertimbangan".

${ }^{3}$ Jamil Shaliba, al-Mu'jam al-Falsafi, Juz I, Mesir: Dar al-Kitab al-Mishri, 1978, hlm.539.; Kamus Besar Bahasa Indonesia, Jakarta: Balai Pustaka, 1991, hlm.19.

4 Rachmat Djatnika. Sistem Ethika Islami. Jakarta : Pustaka Panji Mas, 1969.Lihat juga A.R.Idhamkholid. Diktat Ilmu Akhlak.Cirebon : Arieha Opigayu. 2018

${ }^{5}$ Zakiah Darajat, dkk. Materi Pokok Pendidikan Agama Islam. Jakarta : Proyek Pembinaan Pendidikan Agama Isslam Pada Perguruan Tinggi Depag dan Universitas Terbuka Depdikbud. 1993., hlm. 238. Selanjutnya ditulis Zakiah Darajat, dkk. Materi Pokok

${ }^{6}$ Ahmad Amin, Al-akhlâq. terjemahan Farid Ma'ruf dalam "Etika (Ilmu akhlaq). Jakarta : Penerbit Bulan Bintang, 1988), hlm. 25. Selanjutnya ditulis Ahmad Amin, Alakhlâq

${ }^{7}$ Ibn Miskawaih, Tahdzîb al-Akhlâq wa Tathhîr al-A'raq. Mesir : al-Maktabat al-Mishriyyah, 1934., hlm 40.

$$
\text { حال للنفس داعية لها الي افعالها من غير فكر ولا روية }
$$


3. Imam Al-Ghazali mendefinisikan akhlak dengan : Sifat yang tertanam dalam jiwa yang dengannya lahirlah berbagai macam dengan gampang dan mudah tanpa memerlukan pemikiran dan pertimbangan. ${ }^{8}$

\section{Pengertian Akhlak Terpuji (Mulia).}

Akhlak terpuji atau akhlak mulia yang disebut dengan alakhlaq al-mahmudah atau al-akhlaq al-karimah.

Akhlak yang terpuji adalah akhlak yang dikehendaki oleh Allah SWT. dan dicontohkan oleh Rasulullah SAW. Akhlak ini dapat diartikan sebagai akhlak orang-orang yang beriman dan bertakwa kepada Allah SWT.

Beberapa contoh dari firman Allah yang mensinyalir tentang indikator akhlak yang terpuji (akhlakul karimah) diantaranya:

Mengucapkan salam. Hal ini sebagaimana dapat dipahami dari firman Allah dalam Al-Quran berikut ini:

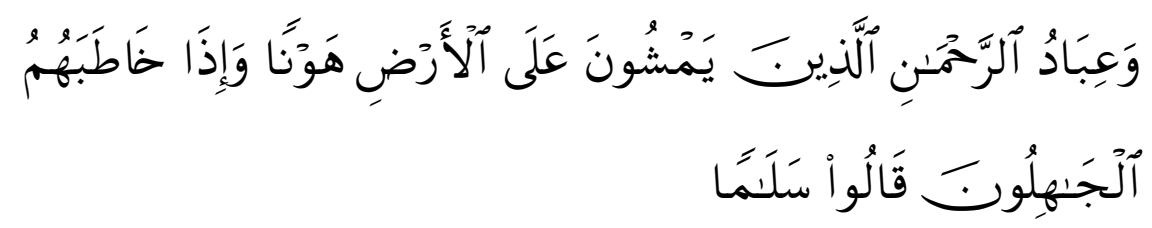

Artinya: "Dan hamba-hamba Tuhan yang Maha Penyayang (ialah) orang-orang yang berjalan di atas bumi dengan rendah hati dan apabila orang-orang jahil menyapa, mereka mengucap-kan kata-kata (yang mengandung) keselamatan. $^{9}$

Firman Allah SWT. tersebut menjelaskan jenis akhlak orang-orang yang menyebarkan kasih kepada sesama manusia. Indikatornya adalah tidak sombong, rendah hati, dan murah senyum. Meskipun orang jahil menyapanya, orang yang berakhlak

${ }^{8}$ Al-Ghazali, Ihyâ 'Ulûm al-Dîn. jilid 3. Beirut : Dar al-Fikr, t.t., hlm. 56. Dalam bahasa aslinya

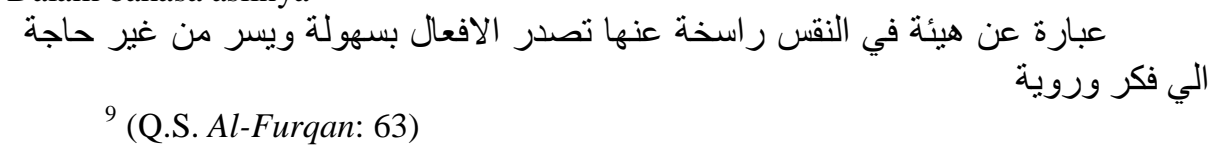


mulia akan menyapanya dengan sapaan yang menyejukkan dan menyelamatkan.

Memafkan kesalahan orang lain. Hal ini dapat dipahami dari irman Allah dalam Al-Quran yang menjelaskan bahwa Allah selalu menerima taubat dari hamba-hamba-Nya kecuali syirik.

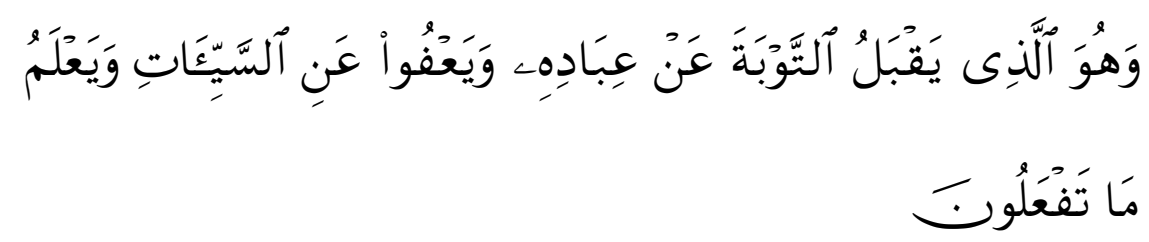

Artinya: "Dan Dialah yang menerima tobat dan hamba-hambaNya, memaafkan kesalahan-kesalahan, dan mengetahui apa yang kamu kerjakan." 10

Ayat di atas, menjelaskan akhlak Allah SWT, yang selalu menerima tobat hamba-Nya dan mengampuni kesalahan-kesalahan orang yang bertobat. Hal itu merupakan pelajaran berharga bagi manusia bahwa manusia yang berakhlak mulia adalah manusia yang pemaaf kepada orang lainAyat Demikian pula, dalam surat Asy-Syura ayat 15, Allah SWT. berfirman:
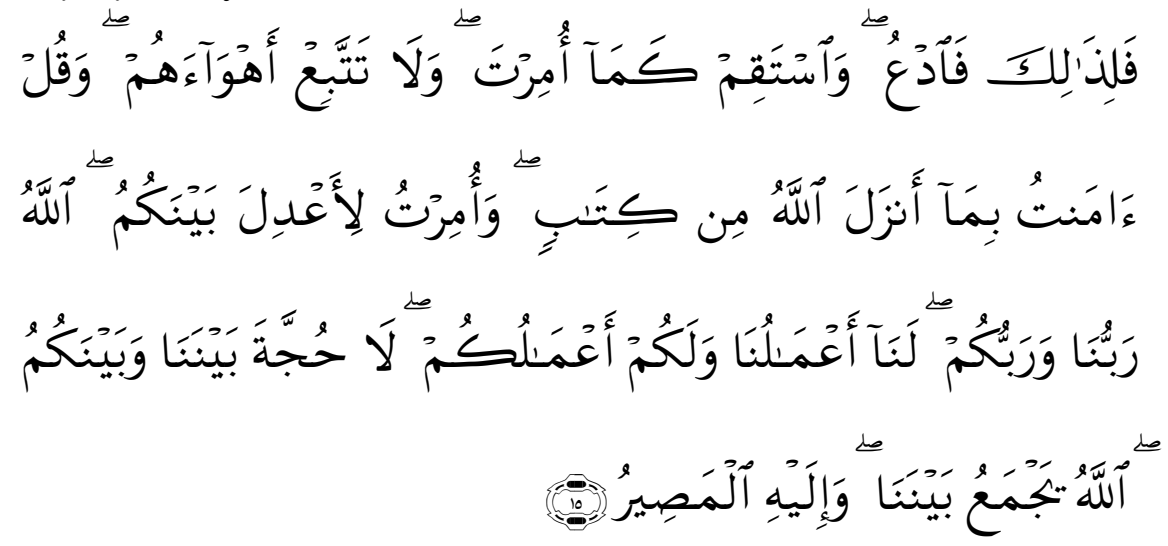

Artinya: Maka Karena itu Serulah (mereka kepada agama ini) dan tetaplah, ${ }^{11}$ sebagai mana diperintahkan kepadamu dan janganlah mengikuti hawa nafsu mereka dan Katakanlah: "Aku beriman kepada semua Kitab yang diturunkan Allah

${ }^{10}$ (Q.S. Asy-Sy ura: 25)

${ }^{11}$ Maksudnya: tetaplah dalam agama dan lanjutkanlah berdakwah. 
dan Aku diperintahkan supaya berlaku adil diantara kamu. Allah-lah Tuhan kami dan Tuhan kamu. bagi kami amal-amal kami dan bagi kamu amal-amal kamu. tidak ada pertengkaran antara kami dan kamu, Allah mengumpulkan antara kita dan kepada-Nyalah kembali (kita)". ${ }^{12}$

Akhlak yang baik lainnya adalah berta'aruf dan bertakwa.. Hal ini sebagaimana dijelaskan dalam Al-Quran dalam surat $\mathrm{Al}$ Hujurat ayat 13:

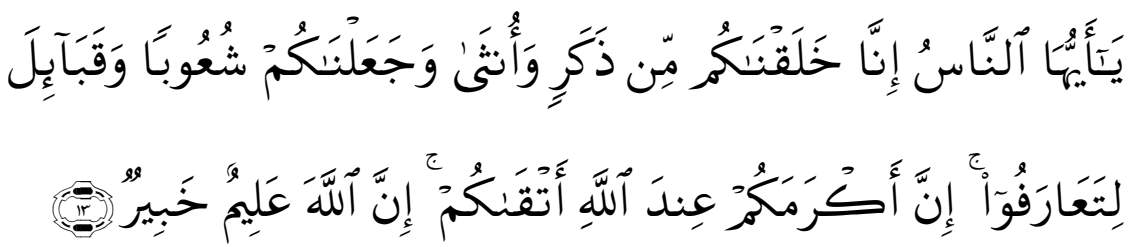

Artinya: "Wahai manusia! Sungguh, Kami telah menciptakan kamu dari seorang laki- laki dan seorang perempuann, kemudian Kami jadikan kamu berbangsa-bangsa dan bersuku-suku agar kamu saling mengenal. Sungguh, yang paling mulia di antara kamu di sisi Allah adalah orang yang paling bertakwa. Sungguh, Allah Maha Mengetahui, Mahateliti."13

Itulah firman Allah SWT. yang kembali memberikan penjelasan tentang keberagaman berbudaya, berbangsa, dan etnis manusia. Manusia dituntun untuk saling berinteraksi dengan sesama manusia. Pergaulan manusia harus dikembangkan seluas mungkin, tetapi bagi Allah SWT., evaluasi terakhir yang dijadikan patokan utama adalah ketakwaan manusia.

contoh dari firman Allah yang mensinyalir tentang indikator akhlak yang tercela (akhlakul madzmumah) diantaranya:

Berbuat dosa dan menganggap diri suci. Hal ini dapat dipahami dari Firman Allah dalam Al-Quran surat An-Najm ayat 32:

12 (Q.S. Asy-Syura: 15)

${ }^{13}$ (Q.S. Al-Hujurat: 13) 


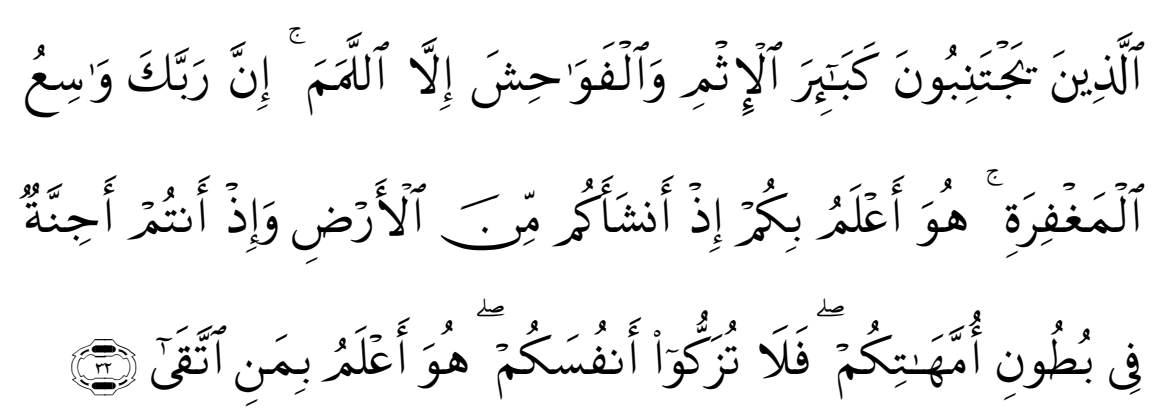

Artinya: "(Yaitu) mereka yang menjauhi dosa-dosa besar dan perbuatan keji, kecuali kesalahan-kesalahan kecil. Sungguh, Tuhanmu Mahaluas ampunan-Nya. Dia mengetahui tentang kamu, sejak Dia menjadikan kamu dari tanah, lalu ketika kamu masih janin dalam perut ibumu; maka janganlah kamu menganggap dirimu suci. Dia mengetahui tentang orang yang bertakwa." 14

Firman Allah SWT. di atas, dapat dipahami dengan logika antagonistika, yaitu kebalikan dari makna aslinya bahwa akhlak yang buruk diindikasikan oleh perbuatan manusia yang selalu berbuat dosa dan menganggap dirinya suci, sehingga ia akan lupa untuk bertobat kepada Allah SWT.

Contoh lain dari indicator akhlak tercela adalah sombong. Hal ini dapat dipahami dari firman Allah dalam al-Quran berikut ini:

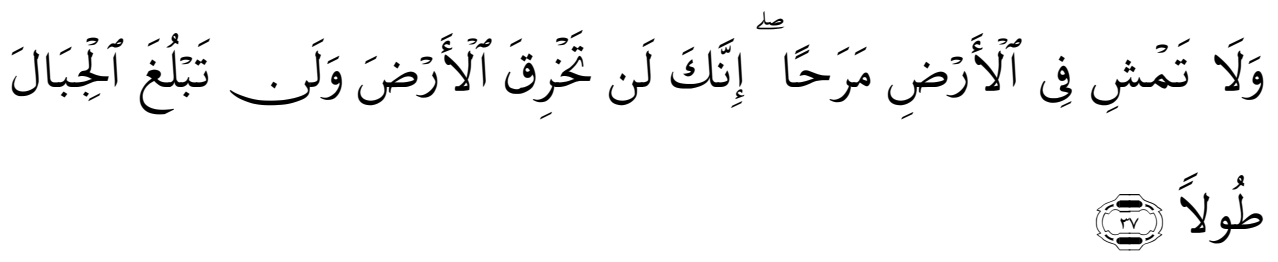

Artinya: "Dan janganlah kamu berjalan di muka bumi Ini dengan sombong, Karena Sesungguhnya kamu sekali-kali tidak dapat menembus bumi dan sekali-kali kamu tidak akan sampai setinggi gunung". ${ }^{15}$

${ }_{15}^{14}$ (Q.S. An-Najm: 32)

15 (Q.S. Al-Isra': 37) 
Tujuan dari asing-masing sesuatu, walaupun berbeda-beda, semuanya akan bermuara kepada satu tujuan yang dinamakan baik, semuanya mengharapkan mendapatkan yang baik dan bahagia, tujuan yang akhir yang sama ini dalam ilmu Ethik "Kebaikan Tertinggi", yang dengan istilah Latinnya disebut "Summum Bonum" atau bahasa Arabnya Al-Khair al-Kully. Kebaikan tertinggi ini bisa juga disebut kabahagiaan yang universal atau Universal HappinessKebaikan yang berhubungan dengan tujuan ini dapat dibedakan dengan kebaikan sebagai tujuan terakhir (Summum Bonum). Dan kebaikan sebagai cara/jalan/sasaran/alat untuk sampai kepada tujuan akhir tersebut. Kabaikan sebagai alat dapat juga berupa tujuan akhir tersebut. Kabaikan sebagai alat ini dapat juga berupa tujuan sementara untuk mencapai tujuan akhir. Tujuan sementara ini mungkin hanya sekali bagi seseorang atau suatu golongan. Tujuan sementara sebagai alat/jalan untuk mencapai tujuan akhir ini terdapat bermacam-macam dan beraneka ragam.

Di dalam akhlak Islamiyah, antara baik sebagai alat/cara/tujuan sementara harus segaris/sejalan dengan baik sebagai tujuan terahir. Artinya cara untuk mencapai tujuan baik sebagai tujuan sementara dan tujuan akhir berada dalam satu garis lurus yang berdasarkan satu norma. Disamping "baik" juga harus "benar". Sebab tidak semua cara yang berharga untuk mencapai tujuan itu disebut baik apabila tidak segaris dengan baik sebagai tujuan akhir.

Tujuan akhir dari setiap orang adalah bahagia. Untuk mencapai kebahagiaan masa kini dan masa nanti orang berusaha untuk mencapainya.Jalan yang dipilih yang menghubungkan keinginan dan tujuan itu berbeda-beda. Ada yang memilih melalui studi untuk mendapatkan ilmu, yang dengan imunya menjadi jalan untuk sampai kepada kebahagiaannya. Ada yang dengan menjadi pengusaha yang dengan jalan ini akan dapat sampai kepada kebahagiaannya. Semua ini sebagai tujuan pertama yang harus ditempuh terlebih dahulu utuk mencapai tujuan selanjutnya.

Dalam akhlak Islamiyah, sarana/cara yang sampai pada tujuan-tujuan itu tetap harus segaris, yaitu yang normatif baik, yaitu bahwa umpamanya untuk menjadi sarjana, ia harus belajar, 
untuk belajar ia perlu buku-buku dan kitab-kitab kepustakaan. Untuk mempunyai kitab-kitab ia harus membeli buku-buku dan kitab-kitab itu, tidak boleh mengambil kepunyaan orang lain atau kepunyaan perpustakaan. Untuk menjadi pengusaha yang kaya ia harus berusaha dengan jalan yang halal, tidak dengan menganiaya orang lain, tidak boleh menimbun dengan jalan riba, tidak dengan korupsi, tidak dengan yang dilarang oleh peraturan-peraturan yang berlaku. Karena disamping baik harus benar. ${ }^{16}$

Di dalam akhlak Islamiyah, untuk mencapai tujuan baik harus dengan jalan yang baik dan benar. Sebab ada garis yang jelas antara yang boleh dan yang tidak boleh; ada garis demarkasi antara yang boleh dilampaui dan yang tidak boleh dilampaui; garis pemisah antara yang halal dan yang haram. Semua ornag muslim harus melalui jalan yang dibolehkan dan tidak boleh melalui jalan yang dilarang. Bahkan antara yang halal dan yang haram tidak jelas, disebut subhat, orang muslim harus berhati-hati, jangan sampai jatuh di daerah yang syubhat, sebab dikhawatirkan akan jatuh di daerah yang haram.

Jadi menurut akhlak Islam, perbuatan itu di samping baik juga harus benar, yang benar juga haras baik. Sebab dalam Ethik yang benar belum tentu baik dan yang baik beium tentu benar. Seperti memberitahu dan menasehati adalah benar; tapi kalau memberitahu dan menasehati itu dengan mengejek atau sambl menghina adalah tidak baik. Belum tentu yang benar itu kalau dijelaskan menjadi baik, seperti kalau seorang suami berkata dengan jujur kepada istrinya bahwa tadi pagi di jalan ia bertemu dengan bekas pacarnya yang dulu dan dia menanyakan apa kabar. Walaupun hal itu benar dan yang sebenamya, tak perlu diberitahukan kepada istri, sebab dengan diberitahukan kepada istri itu, istri kita jadi tersinggung hatinya dan tentu akan mempunyai rasa mendongkol atau timbul cemburu, bahkan mungkin akan menimbulkan percekcokan.

Kalau ada orang yang bertengkar-bermusuhan sehingga yang satu man membunuh yang lainnya dan yang akan dibunuh itu sembunyi di tempat kita, kalau kita berkata dengan jujur dan yang

${ }^{16}$ Rachmat Djatnika. Sistem Ethika Islami., hlm. 36 
sebenarnya akan menimbulkan hal yang tidak baik, bahkan akan menimbulkaa perbuatan melanggar kebenaran yang membiarkan pembunuhan. Karena itu dalam kasus tersebut yang baik adalah tidak memberitahukan, sehingga orang akan selamat, yang dengan tidak memberitahukan itu kita melindungi jiwa dari pembunuhan dan menolong orang yang akan membunuh untuk tidak melakukan pelanggaran dan dosa besar. ${ }^{17}$

\section{Aliran Tentang Baik Dan Buruk}

\section{a. Aliran Hedonisme}

Aliran Hedonisme berpendapat bahwa norma baik dan buruk adaiah "kebahagiaan". ${ }^{18}$ karenanya suatu perbuatan apabila dapat mendatangkan kebahagiaan maka perbuatan itu baik, dan sebaliknya perbuatan itu buruk apabila mendatangkan penderitaan. $^{19}$

Menurut aliran ini, setiap manusia selalu menginginkan kebahagiaan, yang merupakan dorongan daripada tabiatnya dan ternyata kebahagiaan adalah merupakan tujuan akhir dari hidup manusia, oleh karenanya jalan yang mengantarkan ke arahnya dipandang sebagai keutamaan (perbuatan mulia/baik).

Aliran Hedonisme, bahkan tidak saja mengajarkan agar manusia mencari kelezatan, karena pada dasarnya tiap-tiap perbuatan ini tidak sunyi dari kelezatan tetapi aliran ini justru menyatakan: hendaklah manusia itu mencari sebesar-besar kelezatan, dan apabila ia disuruh memilih di antara beberapa perbuatan wajib ia memilih yang paling besar kelezatannya. ${ }^{20}$

Maksud paham ini adalah bahwa manusia hendaknya mencari kelezatan yang sebesar-besarnya bagi dirinya. Dan setiap perbuatannya haras diarahkan kepada kelezatan. Maka apabila terjadi keraguan dalam memilih sesuatu perbuatannya,

${ }^{17}$ Ibid., hal 39.

${ }^{18}$ Maksud dari "kebahagiaan" menurut aliran ini adalah hedone, yakni kelezatan, kenikmatan dan kepuasan rasa serta terhindar dari penderitaan. Karenanya kelezatan bagi aliran ini adalah merupakan ukuran dari perbuatan, jadi perbuatan dipandang baik menurut kadar kelezatan yang terdapat padanya dan sebaliknya perbuatan itu buruk menurut kadar penderitaan yang ada padanya.

${ }^{19}$ H.A. Mustofa., Akhlak Tasawuf., hlm. 64

${ }^{20}$ Ibid., 
harus diperhitungkan banyak sedikitnya kelezatan dan kepedihan-nya. Dan sesuatu itu baik apabila diri seseorang yang melakukan perbuatan mengarah kepada tujuan.

\section{2). Aliran Unilitarianisme}

Maksud dan paham ini adalah agar manusia dapat mencari kebahagiaan sebesar-besarnya untuk sesama manusia atau semua makhluk yang merniliki perasaan.

Kelezatan menurut paham ini, bukan kelezatan yang melakukan perbuatan itu saja, sebagaimana dikatakan oleh pengikut Epicurus, tetapi kelezatan semua orang yang ada hubungannya dengan perbuatan itu. Wajib bagi si pembuat, dikala menghitung buah perbuatannya, jangan sampai berat sebelah dirinya, tetapi harus menjadikan sama antara kebaikan dirinya dan kebaikan orang lain.

\section{Aliran Intuitionisme}

Aliran Intuitionisme berpendirian bahwa setiap manusia mempunyai kekuatan naluri batiniah yang dapat membedakan sesuatu itu baik atau buruk dengan hanya selintas pandang. Jadi, sumber pengetahuan tentang suatu perbuatan mana yang baik atau mana yang buruk adalah kekuatan naluri, kekuatan batin atau bisikan had nurani yang ada pada tiap-tiap manusia.

Oleh karena itu, apabifa seseorang melihat sesuatu perbuatan, maka pada dirinya timbul semacam ilham yang memberi petunjuk tentang nilai perbuatan itu dan selanjutnya ditetapkanlah hukum perbuatan itu baik atau buruk. Dengan demikian, maka kebanyakan manusia sependapat atas keutamaan sifat benar, dermawan ataupun berani dan semacamnya, demikian pula mereka sepakat atas sifat-sifat kebalikannya yang cela dan keji.

Para pengikut aliran Intuisi, berpendapat bahwa manusia mengerti hal-hal yang baik dan yang buruk secara langsung dengan melihatnya sekilas pandang. Perbuatan-perbuatan baik dan buruk diukur dengan daya labial batirtiah, karenanya dikatakan, benar adalah wajib karena benar termasuk sifat utama bukan karena damrat dan karena pendirian orang banyak atau 
jaminan kemewahan serta bukan berarti sebab di luar dari tabiatnya. Demikian pula pencurian adalah buruk karena dalam tabiatnya termasuk sifat melampaui batas/permusuhan pada orang lain dan merampas kekuasaannya dengan tanpa hak. ${ }^{21}$

\section{Aliran Evolutionisme}

Faham evolusi, ${ }^{22}$ pertama muncul di bawa oleh seorang ahli pengetahuan bernama "LAMARCK". Dia berpendapat bahwa jenis-jenis binatang itu merubah satu sama lainnya. Dan menolak pendapat yang mengatakan bahwa jenis-jenis itu berbeda-beda dan tidak dapat berubah-ubah. Alasan lain bahwa jenis-jenis itu tidak terjadi pada satu masa akan tetapi bermula dari binatang rendah, meningkat dan beranak satu dari lainnya dan berganti dari jenis ke jenis lain.

Pengikut paham ini berpendapat bahwa segala perbuatan akhlak itu tumbuh dengan sederhana, dan mulai naik dan meningkat sedikit demi sedikit, lalu berjalan menuju kepada citacita, dimana cita-cita ini ialah yang menjadi tujuan. Maka perbuatan itu baik bila dekat dengan cita-cita itu, dan buruk bila jauh darinya. Tujuan manusia di dalam hidup ini mencapai citacita itu atau mendekatinya sedapat mungkin.

\section{Aliran Idealisme}

Aliran Idealisme dipelopori oleh Immanuel Kant (1724 1804) seorang yang berkebangsaan Jerman. ${ }^{23}$ Pokok-pokok pandangan etika Idealisme dapat disimputkan sebagai berikut:

1). Wujud yang paling dalam dari kenyataan (hakikat) ialah kerohanian. Seseorang berbuat baik pada prinsipnya bukan karena dianjurkan orang lain melainkan atas dasar "kemauan sendiri" atau "rasa kewajiban". Sekalipun diancam dan dicela orang lain, perbuatan baik itu dilakukan juga, karena adanya rasa kewajiban yang bersemi dalam rohani manusia.

${ }^{21}$ Ibid., hlm. 72

${ }^{22}$ Ada dua faktor pergantian yaitu: 1). Lingkungan : Mengadakan penyesuaian dirinya menurut keadaan. 2) Warisan :Bahwa sifat-sifat tetap pada pokok, sesuai dengan pertengahan berpindah pada cabang-cabangnya.

${ }^{23}$ Ibid., 
2). Faktor yang paling penting mempengaruhi manusia adalah "kemauan" yang melahirkan tindakan yang kongkrit. Dan yang menjadi pokok di sini adalah "kemauan baik".

3). Dari kemauan yang baik itulah dihubungkan dengan suatu hal yang menyempurnakannya yaitu "rasa kewajiban". Deiigan demikian, maka menurut aliran ini "kemauan" adalah merupakan faktor terpenting dari wujudnya tindakan-tindakan yang nyata. Oleh karena itu "kemauan yang baik " adalah " menjadi dasar pokok dalam etika Idealisme.

Menurut Kant, untuk dapat terealisasinya tindakan dari kemauan yang baik, maka kemauan yang perlu dihubungkan dengan suatu hal yang akan menyempurnakannya, yaitu " perasaan kewajiban". Jadi, ada kemauan yang baik, kemudian disertai dengan perasaan kewajiban menjalankan sesuatu perbuatan/tindakan, maka terwujudlah perbuatan/ tindakan yang baik.

Perlu dijelaskan di sini, bahwa rasa kewajiban itu terlepas dari kemanfaatan, dalam arti kalau kita mengerjakan sesuatu karena perasaan kewajiban, maka kita tidak boleh/perlu memikirkan apa untung dan ruginya dari pekerjaan/perbuatan itu. Jadi, rasa kewajiban itu tidak dapat direalisasi lagi kepada elemen-elemen yang lebih kecil, dalam arti kewajiban itu hanya untuk kewajiban semata. ${ }^{24}$

Immanuel Kant (1725 - 1804) juga menjelaskan pokok pedoman untuk menentukan hukum suatu perbuatan itu menurut etika atau tidak, yakni:

1). Bertindak sedemikian nipa, sehingga orang dapat menjadikan pedoman tindakannya itu sebagai suatu peraturan umum. Umpamanya, berbohong itu tidak dapat dibuat pedoman untuk umum. Jadi, bohong itu tidak baik.

2). Bertindaklah selamanya sedemikian rupa, sehingga seseorang melayani orang lain sebagai suatu tujuan akhir (end $=$ ghayah), bukan sebagai suatu perantara atau alat (wasilah).

3). Bertindaklah selamanya sedemikian rupa, sehingga pedoman perbuatan itu menunjukkan otonomi kemauan. Jadi pokok

${ }^{24}$ Ibid., hlm. 76 
kemauan itu harus otonom, tidak terpengaruh oleh kemauankemauan dari luar.

Jelasnya bahwa pokok-pokok pandangan Immanuel Kant adalalah sebagai berikut:

1). Wujud yang paling dalam dari kenyataan (hakikat) ialah kerohanian. Seseorang berbuat baik pada prinsipnya bukan karena dianjurkan orang lain melainkan atas dasar kemauan sendiri atau rasa kewajiban. Sekalipun diancam dan dicela orang lain, perbuatan baik itu dilakukan juga karena adanya rasa kewajiban yang bersemi dalam rohani manusia.

2). Faktor yang paling penting mempengaruhi manusia ialah kemauan yang melahirkan tindakan yang kongkrit. Dan yang menjadi pokok di sini adalah kemauan yang baik.

3). Dari kemauan yang baik itulah dihubungkan dengan suatu hal yang menyempurnakannya yaitu rasa kewajiban.

\section{Aliran Tradisionalisme}

Tiap umat manusia mempunyai adat/tradisi dan peraturan tertentu, yang dianggap baik untuk dilaksanakan. Karena manusia itu, kapan dan di mana pun juga, dipengaruhi oleh adat kebiasaan/tradisi bangsanya, karena lahir dalam lingkungan bangsanya itu. jadi seandainya manusia itu menyalahi adatistiadat bangsanya, maka hal itu sangat dicela dan dianggap ke luar dari golongannya.

Jelasnya, dapatlah disebutkan di sini bahwa aliran tradisionalisme adalah aliran yang berpendapat bahwa yang menjadi norma baik dan buruk ialah tradisi atau adat kebiasaan. Artinya sesuatu itu baik kalau sesuai dengan adat kebiasaan, dan sebaliknya sesuatu itu buruk bila menyalahi adat kebiasaan. ${ }^{25}$

Adapun sumber daripada adat kebiasaan antara lain dari:

1). Perbuatan-perbuatan yang dilakukan oleh nenek moyangnya, karena terdorong oieh instansinya.

2). Perbuatan/peristiwa secara kebetulan, meskipun tidak berdasar-kan kepada akal. Seperti harapan baik bagi

${ }^{25}$ Ibid., hlm. 78 
beberapa golongan manusia atas perbuatan yang mereka lakukan pads suatu waktu dan harapan buruk di lain waktu. Hal demikian itu karena keadaan nenek moyangnya pernah mengalami kejadian-kejadian yang buruk pada waktu hidupnya seperti karamnya kapal ke dalam laut, meniupnya angin ribut, sehingga menimbulkan suatu kesimpulan yang tidak tepat, bahwa suatu perbuatan itu kalau diulang melakukannya pada waktu itu tentu akan terjadi seperti dahulu kala.

3). Anggapan baik dari nenek moyangnya terhadap sesuatu perbuatan yang akhirnya diwariskan secara turun temurun.

4). Perbuaian orang-orang terdahufu, mencoba melakukan perbuatan-perbuatan yang akhirnya mengetahui yang berguna dan ber-manfaat, lalu mengetahui yang merugikan maka mereka menying-kirkannya dan memperingatkan orang-orang agar menjauhinya.

Adat kebiasaan yang berupa perintah dilakukan dan yang berupa larangan disingkirkan karena beberapa hal:

1). Pendapat umum, karena memuji pengikut-pengikut adatkebiasaan dan mengejek orang-orang yang menyalahinya. Maka adat-istiadat bangsa dalam berpakaian, makan, bercakap-cakap, benandang dan sebagainya amatlah kuat dan kokoh, karena orang-orang meng-anggap baik bagi pengikutnya dan menganggap buruk bagi orang yang menyalahinya.

2). Apa yang diriwayatkan turun temurun dari hikayathikayat dan khurafat-khurafat yang menganggap bahwa setan dan jin akan membalas dendam kepada orangorang yang menyalahi perintah-perintah adat-istiadat dan malaikat akan memberi pahala bagi yang mengikutinya.

3). Beberapa upacara, keramaian, pertemuan dan sebagainya, yang menggerakan perasaan dan yang mendorong bagi para hadirin untuk mengikuti adatistiadat kernatian, pengantin, ziarah kubur, dan upacara Jain-lainnya. ${ }^{26}$

${ }^{26}$ Ibid., hlm. 78-79 


\section{g. Aliran Naturalisme}

Yang menjadi ukuran baik dan buruknya perbuatan manusia menurut aliran Naturalisme ialah perbuatan yang sesuai dengan fitrah/ naluri manusia itu sendiri, baik mengenai fitrah lahir maupun fitrah batin. Aliran ini menganggap bahwa kebahagiaan yang menjadi tujuan daripada setiap manusia didapat dengan jalan memenuhi panggilan nature atau kejadian manusia itu sendiri. Itulah sebabnya, atiran tersebut dinamakan naturalisme.

Aliran ini berpendirian bahwa segala sesuatu dalam dunia ini menuju kepada suatu tujuan tertentu. dengan memenuhi panggilan nature setiap sesuatu akan dapat sampai kepada kesempurnaan. Benda-benda dan tumbuh-tumbuhan juga termasuk di dalamnya, menuju kepada tujuan yang satu, tetapi dapat dicapainya secara otomatis tanpa pertimbangan atau perasaan. Hewan menuju kepada tujuan itu dengan naluri kehewanannya, sedangkan manusia menuju tujuan itu dengan naluri akal pikirannya. ${ }^{27}$

\section{h. Aliran Theologis}

Aliran ini berpendapat bahwa yang menjadi ukuran baik dan buruknya perbuatan manusia, adalah didasarkan alas ajaran Tuhan, apakah perbuatan itu diperintahkan atau dilarang oleh-Nya. Segala perbuatan yang diperintahkan Tuhan itulah yang baik dan segala perbuatan yang dilarang oleh Tuhan itulah perbuatan yang buruk, di mana ajaranajaran tersebut sudah dijelaskan dalam kitab suci. Dengan perkataan theologis saja nampaknya masih samar karena di dunia ini terdapat bermacam-macam agama yang mempunyai kitab suci sendiri-sendiri, yang antara satu dengan yang lain tidak sama, bahkan banyak yang bertentangan. Masingmasing penganut agama menyadarkan pendiriannya kepada ajaran Tuhan. ${ }^{28}$

${ }^{27}$ Ibid., hlm. 80

${ }^{28}$ Ibid., hlm. 81 
Sebagai jalan ke luar dari kesamaran itu, ialah dengan mengkaitkan etika theologis ini dengan jelas kepada agama, misalnya: etika theologis menurut Kristen, etika theologis menurut Yahudi dan etika theologis menurut Islam. Hal ini dilakukan oleh ahli filsafat mengingat perkataan theologis menurut pandangan mereka masih bersifat umum, sehingga perlu ada kejelasan etika theologis mana yang dimaksudkan.

\section{Kesimpulan}

Baik dan buruk menurut seseorang dengan yang lainnya pasti tidaklah sama. Hal ini sering ditemu sesuatu menurut orang tertentu dianggap baik namun menurut yang lainnya dianggap tidak baik/burut. Karena itu untuk dapat menentukan apakah sesuatu itu dianggap baik atau buruk diperlukan adanya ukuran/standar yang dapat digunakan untuk mengukur/mentukan baik buruknya sesuatu/suatu perbuatan. Dengan adanya standar/okuran tentang baik buruk maka meskipun pandangan orang tentang baik buruk bervariatif, tetapakan bisa diukur dengan standar tersebut.Standar yang bisa dijadikanukuran untuk menentukan baik atau buruk adalah akhlak

\section{DAFTAR PUSTAKA}

A.R. Idhamkholid. Diktat.Mengenal Tasawuf. Cirebon : Arieha Opigayu.3018

---------. Diktat Ilmu Akhlak.Cirebon : Arieha Opigayu. 2018

Abuddin Nata. Akhlak Tasawuf dan Karakter Mulia. Jakarta; PT. Raja Grapindo Persada. 2014.

Ahmad Amin, Al-akhlâq. terjemahan Farid Ma'ruf dalam "Etika (Ilmu akhlaq). Jakarta : Penerbit Bulan Bintang, 1988),

Al-Ghazali, Ihyâ 'Ulûm al-Dîn. jilid 3. Beirut : Dar al-Fikr, t.t.,

Ibn Miskawaih, Tahdzîb al-Akhlâq wa Tathhîr al-A'raq. Mesir : alMaktabat al-Mishriyyah, 1934.

Jamil Shaliba, al-Mu'jam al-Falsafi, Juz I, Mesir: Dar al-Kitab al-Mishri, 1978, .;

Rachmat Djatnika. Sistem Ethika Islami. Jakarta : Pustaka Panji Mas, 1969. 
W.J.S. Poerwadarminta. Kamus Besar Bahasa Indonesia, Jakarta: Balai Pustaka, 1991,

Zakiah Darajat, dkk. Materi Pokok Pendidikan Agama Islam. Jakarta : Proyek Pembinaan Pendidikan Agama Isslam Pada Perguruan Tinggi Depag dan Universitas Terbuka Depdikbud. 1993., 